\title{
Analisis Peran Corporate Social Responsibility terhadap Aspek Sosial, Ekonomi, dan Lingkungan pada Industri Ritel
}

\author{
Abd Rohman Taufiq ${ }^{1, ~ *, ~ A c h m a d ~ I q b a l 2 ~}$ \\ ${ }^{1}$ Universitas PGRI Madiun, Jl. Setia Budi No.85, Kota Madiun, Jawa Timur, \\ Indonesia \\ 2Universitas 17 Agustus 1945 Banyuwangi, Jl. Laksda Adi Sucipto, Kabupaten \\ Banyuwangi, Jawa Timur, Indonesia \\ *(abdrohman.taufiq@gmail.com)
}

\section{Riwayat Artikel: \\ Tanggal diajukan: \\ 2 Oktober 2020 \\ Tanggal diterima: \\ 15 April 2021 \\ Tanggal dipublikasi daring: \\ 25 Juni 2021}

Kata kunci: Comnev; CSR; perusahaan ritel

\begin{abstract}
ABSTRAK
Corporate Social Responsibility (CSR) merupakan tanggung jawab perusahaan bukan hanya tentang bagaimana menghasilkan laba, tetapi juga memperhatikan masyarakat dan lingkungan. Penelitian ini bertujuan untuk menganalisis peran CSR perusahaan ritel di Indonesia. Penelitian menggunakan pendekatan kualitatif. Hasil penelitian menunjukkan bahwa perusahaan ritel di Indonesia telah melaksanakan CSR secara berkelanjutan. Program CSR memiliki implikasi dalam beberapa aspek, diantaranya aspek sosial, ekonomi, dan lingkungan. Pada program sosial, CSR perusahaan retail didominasi oleh kegiatan bantuan pendidikan, bencana alam, dan donor darah. ERAA merupakan perusahaan yang fokus terhadap aspek ekonomi dengan pengembangan komunitas. Aspek lingkungan didominasi kegiatan tanam pohon dan pengurangan energi. Community Development (Comnev) harusnya menjadi dasar pelaksanaan program CSR agar lebih berkelanjutan.
\end{abstract}

\section{Pengutipan:}

Taufiq, Abd Rohman \& Iqbal, Achmad. (2021). Analisis Peran Corporate Social Responsibility terhadap Aspek Sosial, Ekonomi, dan Lingkungan pada Industri Ritel. JIA (Jurnal Ilmiah Akuntansi), Vol. 6, No. 1, Hal: 22-36.

Keywords: Comnev; CSR; retail companies

\section{ABSTRACT}

Corporate Social Responsibility (CSR) is a company responsibility that not only about how to generate profits, but also pay attention to society and the environment. This study aims to analyze the CSR role of retail companies in Indonesia. This research uses a qualitative approach. The results show that retail companies in Indonesia have implemented CSR in a sustainable manner. The CSR program has implications in several aspects, including social, economic, and environmental aspects. In social programs, retail company CSR is dominated by educational assistance activities, natural disasters, and blood donors. ERAA is a company that focuses on economic aspects with community development. Environmental aspects are dominated by tree planting and energy reduction. Community Development (Comnev) should be the basis for implementing CSR programs to be more sustainable. 


\section{PENDAHULUAN}

Perusahaan ritel tumbuh dengan pesat, kondisi ini bukan berarti menutup kesempatan pedagang kecil atau warung tradisional untuk tumbuh dan berkembang. Pemerintah dapat memberikan bentuk untuk masalah pendanaan, sementara pelaku perusahaan ritel dapat memberikan program CSR dalam kepedulian lingkungan dan memberikan dampak positif bagi masyarakat. Pembangunan perusahaan ritel memiliki dampak positif seperti kepedulian lingkungan, kepedulian sosial, dan kepedulian kesehatan (Satriyarti \& Rahayu, 2018)

Pola pembangunan perusahaan ritel juga memiliki tanggung jawab sosial terhadap kesejahteraan sesuai dengan people, planet, dan profit (3P) (Sofyanty et al., 2017) UU No. 40 Tahun 2007 tentang perseroan terbatas, kewajiban pemberian Corporate Social Responsibility (CSR) tersebut hanya terbatas pada perseroan atau perusahaan yang kegiatan usahanya berkaitan dengan Sumber Daya Alam (SDA). CSR juga mempunyai program salah satunya terhadap lingkungan hidup yang berdasarkan UU No. 32 Tahun 2009 tentang perlindungan dan pengelolaan lingkungan hidup dengan benar, akurat, terbuka dan tepat waktu.

Berdasarkan data Asosiasi Pengelola Pusat Belanjan Indonesia (APPBI) minat belanja masyarakat di mall tahun 2019 menunjukkan peningkatan sebesar 10 persen dibanding tahun sebelumnya (tribun.com). Minat belanja masyarakat di mall mengalami peningkatan dikarena fasilitas yang diberikan manajemen sesuai dengan keinginan pelanggan dan mempunyai progam CSR sesuai kebutuhan masyarakat sekitar. Perusahaan dalam meningkatkan kinerja salah satunya adalah menciptakan pelayanan yang efektif dan mempunyai program CSR yang maksimal (Wahudi \& Azheri, 2008).

Salah satu hal yang perlu diperhatikan untuk meningkatkan kinerja perusahaan ritel yaitu menciptakan pelayanan yang efektif dan mempunyai program CSR yang unggul. Pertumbuhan perusahaan ritel di kota metropolitan terus mengalami peningkatan sebesar $10 \%$ pada tahun 2020 dibandingkan dengan tahun 2019 sebesar 7,8\% (CEIC, 2020). Perusahaan ritel selalu memberikan fasilitas belanja secara maksimal sesuai dengan kebutuhan masyarakat. Disisi lain, perusahaan ritel juga mempunyai program CSR 
berupa kepedulian sosial ekonomi dan lingkungan sekitar.

Terdapat 30 unit perusahaan ritel di Indonesia dalam melaksanakan program CSR belum maksimal dalam indikator 3P pada tahun 2020 Penulis memilih perusahaan ritel di Indonesia dikarenakan dalam melaksanakan program CSR berdasarkan indikator 3P belum maksimal. indikator tersebut digunakan untuk mengukur sejauh mana keberhasilan perusahaan ritel dapat menjalankan program CSR secara efektif dan efisien.

Perkembangan kinerja perusaha-an ritel salah satunya dilihat dari program CSR dengan kesatuan 3P (Sopiah \& Syihabudhin, 2008) Perusahaan ritel di Indonesia memberikan kontribusi yang besar terhadap Produk Domestik Bruto (PDB) dan juga menyerap tenaga kerja yang banyak, maka dari itu harus mempunyai tanggungjawab sosial yang tinggi terdahap 3P.

Kehadiran perusahaan ritel pada dasarnya memanfaatkan pola belanja masyarakat kelas menengah ke atas dan memberikan fasilitas yang maksimal, serta kepedulian terhadap lingkungan juga diperhatikan dengan baik (Bell \& Lehman, 1999). Minat belanja di perusahaan ritel sangat diminati masyarakat karena membe- rikan fasilitas yang maksimal dan program CSR selalu diperhatikan sesuai dengan kebutuhan masyarakat sekitar.

\section{TELAAH LITERATUR}

\section{Konsep Corporate Social Responsibility}

Kewajiban perusahaan pariwisata untuk berkontribusi dalam melaksanakan CSR harus membuat industri pariwisata yang berkelanjutan (Mattera \& Alberto, 2016). Industri dalam melaksanakan kegiatan berkelanjutan merupakan bisnis tanpa merugikan generasi yang akan datang. Selain itu perusahaan harus berkomitmen dalam pengembangan ekonomi berkelanjutan yang menitik beratkan pada keseimbangan terhadap aspek sosial, ekonomi, dan lingkungan (I. W. Sidarta, 2016). Selain itu, industri berkelanjutan juga mempu-nyai konsep triple bottom line dalam program CSR. Konsep tersebut selain mengejar profit, seharusnya perusaha-an juga memperhatikan dan terlibat dalam pemenuhan kesejahteraan masyarakat (people) dan juga berkontribusi aktif dalam menjaga kelestarian lingkungan sekitarnya (planet). 
Lingkungan

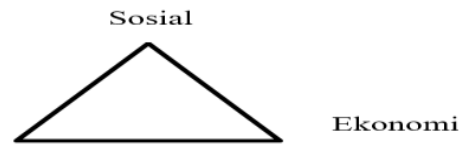

Gambar 1. Hubungan Konsep Triple Bottom Line

Gambar 1 menjelaskan bahwa perusahaan harus memperha-tikan ketiga aspek pada konsep triple bottom line, Pertama, profit merupakan unsur yang paling penting dan utama dalam setiap pelaku usaha yang diperoleh dari pendapatan yang digunakan untuk menjamin kelangsungan hidup perusahaan. Kedua, people adalah bagian terpenting bagi kelangsungan hidup perusahaan, karena people merupakan salah satu unsur pendukung yang menentukan kelansungan hidup dan juga perkembangan perusahaan. Oleh karena itu perusahaan harus perlu berkomitmen untuk berupaya memberikan manfaat yang sebaikbaiknya kepada masyarakat sekitar. Dan ketiga planet, apabila perusahaan ingin mempertahankan eksistensinya dan agar dapat diterima olah masyarakat, maka perusahaan tersebut juga harus menyertakan pula tanggung jawabnya terhadap lingkungan sekitar. Perusahaan dengan lingkungan merupakan hubungan konstan yang saling berkaitan untuk dirawat dengan maksimal yang mempunyai manfaat yang baik bagi perusahaan.

Selain itu, perusahaan harus mempunyai prinsip tanggungjawab sosial yang bersifat transparansy, accountability, responsibility, independency, dan fairness (Yapiter, 2013). Prinsip tanggung jawab sosial merupakan hal yang harus diwajibkan dalam melaksanakan kegiatan perusahaan berkelanjutan. Keberhasilan ekonomi dan financial dunia untuk menerapkan prinsip tanggung jawab sosial berhubungan erat dengan kondisi sosial dan lingkungan dimana perusahaan tersebut beroperasi. Penerapan bentuk CSR digolongan menjadi empat bentuk (Wahudi \& Azheri, 2008), yaitu: pengelolaan lingkungan kerja, menjamin kemitraan, penanganan kelestarian lingkungan, dan investasi sosial dengan kegiatan amal perusahaan dengan memberikan dukungan finansial dan non finansial untuk menunjang kegiatan sosial.

\section{Dampak Kehidupan Sosial Ekonomi}

Komponen dan fungsi sistem ekonomi untuk mengetahui besarnya dampak yang ditimbulkan oleh suatu kegiatan (I. Sidarta, 2018). Pertama, sistem ekonomi tersusun atas hubungan timbal balik para pelaku ekonomi. Kedua, sistem ekonomi 
mengatur perubahan persediaan bahan mentah menjadi barang jadi. Ketiga, sistem ekonomi menentukan distribusi dari barang dan jasa yang diperlukan. Keempat, sistem ekonomi mempengaruhi presepsi ruang barang dan jasa yang dibutuhkan.

Program CSR dapat memberikan dampak sosial (Yapiter, 2013) diantaranya: memberikan perhatian penuh kepada masyarakat yang kebutuhan, menjalin hubungan yang baik, memberikan fasilitas mendukung, penghijauan lingkungan sekitar, dan beasiswa. CSR merupakan komitmen perusahaan untuk melakukan kontribusi dalam pengembangan ekonomi berkelanjutan untuk bekerjasama dengan masyarakat sekitar untuk meningkatkan kualitas kehidupan perekonomian (Bell \& Lehman, 1999).

\section{Peran Analisis Dampak Sosial}

Dasar peraturan UU yang menyatakan perlunya memperhatikan aspek sosial sebagai berikut:

1) UU No. 17/2007 tentang Rencana Pembangunan Jangka Panjang Nasional

a) Dalam rangka pembangunan berkeadilan, pembangunan sosial juga dilakukan dengan memberi perhatian yang lebih pada kelompok masyarakat yang kurang beruntung, termasuk masyarakat yang tinggal di wilayah terpencil, tertinggal, dan wilayah bencanan.

b) Penguatan kelembagaan dan jaringan pengarusutamaan gender dan anak di tingkat nasional dan daerah termasuk ketersediaan data dan statistic gender.

2) UU No. 2/2012 tentang Pengadaan Lahan bagi Pembangunan untuk Kepetingan Umum; Pasal 3 berbunyi pengadaan tanah untuk kepentingan umum bertujuan menyediaakn tanah bagi pelaksanaan pembangunan guna meningkatkan kesejahteraaan dan kemakmuran bangsa, negara, dan masyarakat dengan tetap menjamin kepentingan huum pihak yang berhak.

3) PP No. 5/2010 tentang Rencana Pembangunan Jangka Menengah Nasional Tahun 2010-2014

a) Perbaikan kesejahteraan rakyat dapat diwujudkan melalui sejumlah program pembangunan untuk penanggulangan kemiskinan dan penciptaan kesempatan kerja, termasuk peningkatan program di bidang Pendidikan, kesehatan, dan percepatan 
pembangunan infrastruktur dasar.

b) Untuk mewujudkan keadilan dan kesetaraan gender, peningkatan akses dan partisipasi perempuan dalam pembangunan harus dilanjutkan.

4) PP No. 15/2010 tentang Percepatan penanggulan Kemiskinan; Pasal 1 berbunyi program penggulangan kemiskinan adalah kegiatan yang dilakukan oleh pemerintah, pemerintah daerah dunia usaha, serta masyarakat untuk meningkatkan kesejahteraaan masyarakat miskin melalui bantuan sosial, pemberdayaan masyarakat, pemberdayaan usaha ekonomi mikro dan kecil, serta program lain dalam rangka meningkatkan kegiatan ekonomi.

5) Instruksi Presiden No. 9 Tahun 2000 tentang Pengarusutamaan Gender dalam Pembangunan Nasional; menginstruksikan kepada Menteri untuk melaksanakan pengarusutamaan gender guna terselenggaranya perencanaan, penyusunan, pelaksa-naan, pemantauan, dan evaluasi atas kebijakan dan program pembangunan nasional yang berperspektif gender sesuai dengan bidang tugas dan fungsi, serta kewenangan masingmasing.

\section{Peran Analisis Ekonomi}

Infrastruktur

memegang peranan yang sangat penting sebagai lokomotif pembangunan daerah dan nasional untuk menggerakan roda pertumbuhan ekonomi. Keberadaan infrastruktur akan mendorong peningkatan produktivitas faktorfaktor produksi, memperlancar mobilitas penduduk, barang dan jasa, juga memperlancar perdagangan antar daerah. Dampak pembangunan Infrastruktur dapat menjadi pendorong pertumbuhan ekonomi, dan sebaliknya pertumbuhan ekonomi sendiri juga dapat menjadi tekanan bagi infrastruktur. Pertumbuhan ekonomi yang positif akan mendorong peningkatan kebutuhan akan berbagai infrastruktur. Perannya sebagai penggerak di sektor perekonomian akan mampu menjadi pendorong berkembangnya sektor-sektor terkait sebagai multiplier dan pada akhirnya akan menciptakan lapangan usaha baru dan memberikan output hasil produksi sebagai input untuk konsumsi.

Dalam pembangunan ekonomi akan memberikan dampak pada pertumbuhan ekonomi dan peningkatan kualitas hidup. 
Pertumbuhan ekonomi sendiri akan berpengaruh terhadap investasi. Sedangkan peningkatan kualitas hidup akan berpengaruh terhadap kesejahteraan masyarakat, karena dengan pembangunan infrastruktur dapat mengurangi kemiskinan dan jumlah pengangguran suatu wilayah. Sebagai penunjang kesejahteraan masyarakat dan investasi pembangunan diperlukan berbagai infrastruktur. Antara lain jaringan jalan, jaringan listrik, jaringan telekomunikasi, air bersih. Dorongan peningkatan pada subsektor listrik, subsektor jalan, subsektor transportasi dan subsektor komunikasi tersebut disebabkan karena tingkat permintaan dari subsektor tersebut terus mengalami peningkatan. Disamping itu, respon permintaan yang terus meningkat terhadap subsektor tersebut diimbangi dengan banyaknya investasi pembangunan infrastrukur di subsektor tersebut.

Sebagai contohnya adalah kebutuhan akan listrik. Indonesia mengalami permasalahan dalam listrik dimana suplai listrik tidak dapat memenuhi kebutuhan akan listrik yang mengakibatkan pemadaman di beberapa daerah secara bergiliran. Padahal listrik tidak hanya dibutuhkan pada rumah tangga-rumah tangga saja, namun juga sangat dibutuhkan pada sektorsektor industri yang akan berdampak pada perekonomian masyarakatnya pula. Maka dari itu infrastruktur jaringan listrik merupakan komponen penting dalam menunjang aktivitas masyarakat dan juga sangat berpengaruh terhadap masalah perekonomian. Begitu pula dengan pembangunan infrastruktur jaringan jalan. Pembangunan jalan sangat tidak kalah penting dan diperlukan sebagai alat penghubung suatu tempat dengan tempat yang lain. Dengan adanya akses jalan yang mudah dijangkau akan mempengaruhi unsur strategis suatu tempat dan dengan mudahnya akses akan mempengaruhi banyaknya pihak swasta yang mau berinvestasi. Dengan banyaknya pihak swasta yang mau berinvestasi tersebut akan mempengaruhi pada pertumbuhan ekonomi yang cukup pesat. Selain itu dengan adanya pembangunanpembangunan infrastruktur salah satu contohnya seperti jaringan jalan juga akan memberi manfaat kesejahteraan masyarakat karena terbebas dari keterpencilan suatu tempat dan memberikan kemudahan akses bagi masyarakat.

Jaringan telekomunikasi pun juga memberi pengaruh terhadap kesejahteraan masyarakat. Dengan adanya banyak stasiun televisi swasta 
saat ini menjadi bukti bahwa cukup banyak investasi swasta di Indonesia di bidang pertelekomunikasian. Apalagi di era globalisasi seperti saat ini, telekomunikasi sangat diperlukan sebagai alat penunjang keberhasilan suatu negara. Dan permintaan akan sarana telekomunikasi saat ini juga semakin meningkat. Sarana air bersih juga mempunyai peran sangat strategis untuk meningkatkan taraf hidup dan derajat kesehatan masyarakat, juga sebagai faktor pendorong bagi pertumbuhan ekonomi. Namun dalam penyediaan baik segi kualitas, kuantitas dan kontinuitas, belum berjalan berkesinambungan. Sisi lain, tuntutan kebutuhan air bersih yang memenuhi standar kesehatan terus mengalami peningkatan tanpa diimbangi dengan perbaikan kualitas pelayanan. Berdasarkan peran dan fungsinya seperti yang telah diungkapkan di atas (sebagai pendorong berkembangnya sektorsektor terkait sebagai multiplier dan pada akhirnya akan menciptakan lapangan usaha baru dan memberikan output hasil produksi sebagai input untuk konsumsi), maka dapat disimpulkan bahwa sektor infrastruktur merupakan fundamental perekonomian.

\section{Peran Analisis Lingkungan}

Kajian lingkungan dibutuhkan untuk memastikan bahwa dalam penyusunan kebijakan telah mengakomodasi prinsip perlindungan dan pengelolaan lingkungan hidup. Adapun amanat perlindungan dan pengelolaan lingkungan adalah sebagai berikut:

1) UU No. $32 / 2009$ tentang Perlindungan dan Pengelolaan Lingkungan Hidup: "Instrumen pencegahan pencemaran dan/atau kerusakan lingkungan hidup terdiri atas antara lain Kajian Lingkungan Hidup Strategis (KLHS), Analisis Mengenai Dampak Lingkungan (AMDAL), dan Upaya Pengelolaan Lingkungan-Upaya Pemantauan Lingkungan (UKL-UPL) dan Surat Pernyataan Kesanggupan Pengelolaan dan Pemantauan Lingkungan Hidup (SPPLH)"

2) UU No. 17/2007 tentang Rencana Pembangunan Jangka Panjang Nasional:

"Dalam rangka meningkatkan kualitas lingkungan hidup yang baik perlu penerapan prinsipprinsip pembangunan yang berkelanjutan secara konsisten di segala bidang"

3) Peraturan Presiden No. 5/2010 tentang Rencana Pembangunan Jangka Menengah Nasional 
Tahun

2010-2014:

"Dalam bidang lingkungan hidup, sasaran yang hendak dicapai adalah perbaikan mutu lingkungan hidup dan pengelolaan sumber daya alam di perkotaan dan pedesaan, penahanan laju kerusakan lingkungan dengan peningkatan daya dukung dan daya tampung lingkungan; peningkatan kapasitas adaptasi dan mitigasi perubahan iklim"

4) Permen LH No. 9 Tahun 2011 tentang Pedoman Umum Kajian Lingkungan Hidup Strategis: Dalam penyusunan kebijakan, rencana dan/atau program, KLHS digunakan untuk menyiapkan alternatif penyempurnaan kebijakan, rencana dan/atau program agar dampak dan/atau risiko lingkungan yang tidak diharapkan dapat diminimalkan

5) Permen LH No. 16 Tahun 2012 tentang Penyusunan Dokumen Lingkungan.

Sebagai persyaratan untuk mengajukan ijin lingkungan maka perlu disusun dokumen Amdal, UKL dan UPL, atau Surat Pernyataan Kesanggupan Pengelolaan Lingkungan Hidup atau disebut dengan dengan SPPL bagi kegiatan yang tidak membutuhkan Amdal atau UKL dan UPL.

\section{Peran CSR Dalam Meningkatkan Pembangunan}

Salah satu solusi dalam meningkatkan pemberdayaan dan pembangunan masyarakat desa adalah dengan memanfaatkan peran aktif pihak ketiga atau swasta melalui peran CSR yang lebih dikenal dengan Tanggung Jawab Sosial Perusahaan atas keberadaannya beroperasi pada sebuah wilayah.

Peraturan Pemerintah No. 47 Tahun 2012 tentang Tanggung Jawab Sosial dan Lingkungan Perseroan Terbatas, dimana tanggung jawab perusahaan adalah melanjutkan komitmen sebagai bisnis untuk bersikap secara ethnic, bermoral dan berkontribusi pada pembangunan ekonomi serta meningkatkan kualitas kehidupan dan tenaga kerja dan keluarganya maupun komunitas lokal dan masyarakat. Perusahaan juga harus mengintegrasi antara kegiatan sosial dan masalah lingkungan yang berhubungan dengan operasi bisnis. Dalam perkembangan pembangunan yang terlambat, belum sepenuhnya dirasakan oleh masyarakat secara merata dan masih banyak infrastruktur jalan yang rusak, dan sarana prasarana yang belum 
maksimal serta alat komunikasi yang belum memadai.

Program pelaksanaan CSR ada lima pilar aktivitas CSR yaitu menciptakan SDM yang handal dan pemberdayaan masyarakat, menjaga keharmonisan dengan masyarakat sekitar, menjalankan tata kelola bisnis yang baik, menjaga kelestarian lingkungan dan dapat menumbuhkan citra positif serta mendapat kepercayaan dan dukungan dari masyarakat (Wibisono, 2007). Pelaksanaan CSR dalam pembangunan, diantaranya mendukung pembangunan infrastruktur, pembangunan masyarakat dan peningkatan kompetensi sumber daya manusia, keamanan lingkungan, kesehatan dan keamanan masyarakat serta kesejahteraan masyarakat.

\section{METODE}

Pendekatan penelitian yang digunakan dalam penelitian ini adalah kualitatif. Penelitian ini bertujuan untuk menganalisis bagaimana CSR yang diterapkan pada perusahaan retail di Indonesia. Data yang digunakan merupakan data sekunder berupa laporan keberlanjutan (sustainability reporting) baik yang dilaporkan secara terpisah dari laporan tahunan maupun tidak terpisah sejak tahun 2017-2019.
Studi dilakukan pada perusahaan retail yang terdaftar di Bursa Efek Indonesia dan masuk dalam indeks LQ45 periode FebruariJuli 2020. Selama periode Februari hingga Juli 2020, terdapat 3 perusahaan ritel yang masuk dalam indeks LQ45 diantaranya Ace Hardware Indonesia Tbk. (ACES), Erajaya Swasembada Tbk. (ERAA), dan Matahari Department Store Tbk. (LPPF).

\section{HASIL DAN PEMBAHASAN}

Sesuai dengan UU No. 40 Tahun 2007 tentang perseroan terbatas serta peraturan Pemerintah No. 47 Tahun 2012, perusahaan retail telah melaksanakan tanggungjawab sosial secara berkelanjutan. Berikut hasil analisis dari masing-masing perusahaan.

\section{Ace Hardware Indonesia Tbk. (ACES)}

ACES secara berkelanjutan berkomitmen untuk berperan aktif dalam pembangunan ekonomi berkelanjutan. Program CSR yang dijalankan oleh ACES senantiasa melibatkan peran aktif dari karyawan. Hal ini bertujuan untuk meningkatkan kepedulian sosial. 
Tabel. 1 Program CSR ACES Tahun 2017-2019

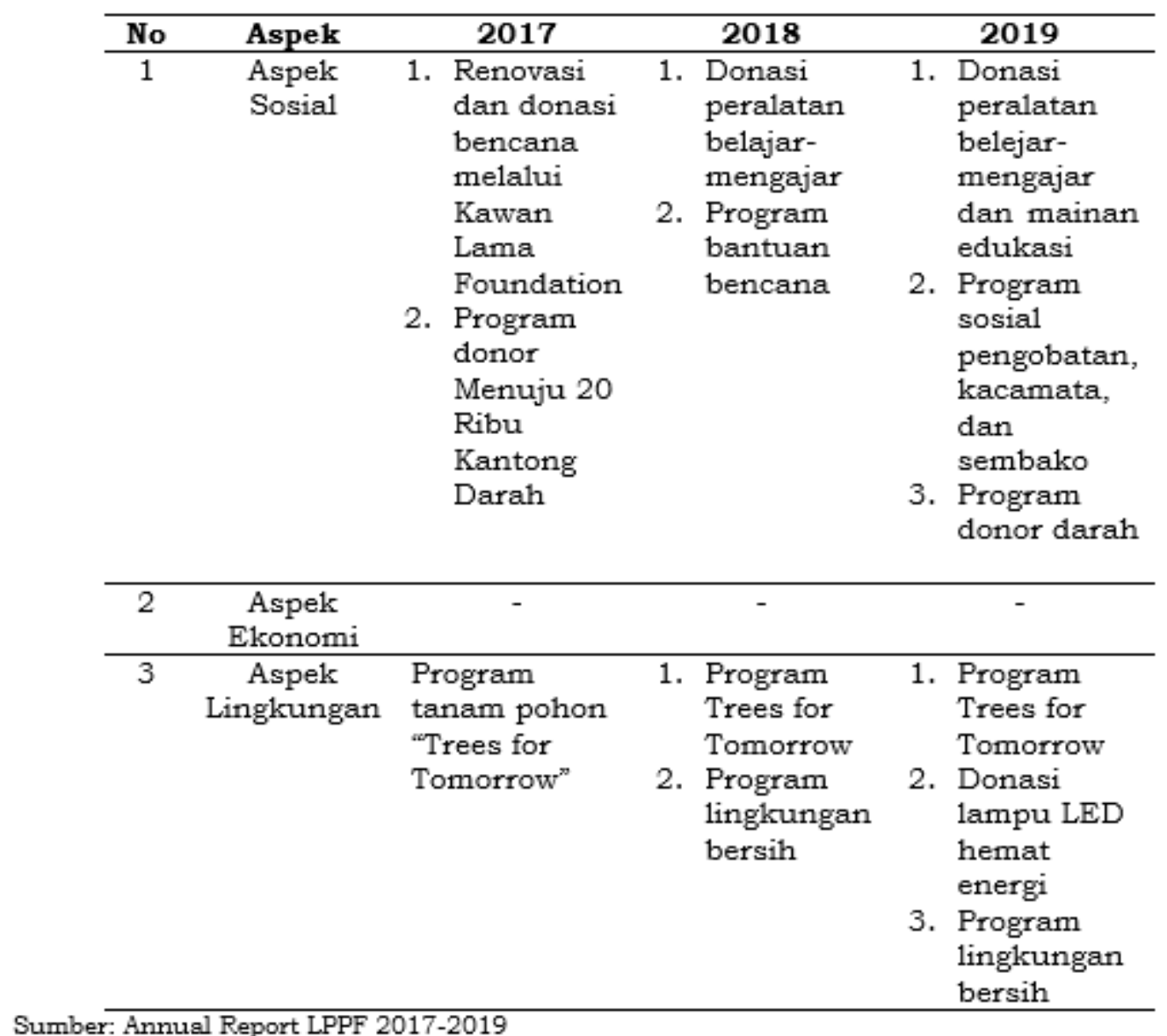

Erajaya Swasembada Tbk. (ERAA)

ERAA memandang CSR sebagai bentuk kepedulian korporasi dalam memberikan kontribusinya untuk pengembangan kesejahteraan ekonomi maupun sosial. Program CSR dilakukan secara berkelanjutan kepada masyarakat didalam ataupun diluar wilayah operasionalnya.

$$
\text { Program CSR dari ERAA }
$$
difokuskan pada aspek pendidikan dan kesejahteraan sosial yang dinaungi oleh Lentera - Erajaya Peduli. Terdapat 3 pilar yang menjadi program Lentera Erajaya Peduli, yakni Lentera Cerdas untuk peningkatan mutu dan kualitas pendidikan, Lentera Sehat untuk peningkatan kualitas kesehatan karyawan maupun masyarakat. Lentera Kasih untuk peningkatan kesejahteraan sosial dan penanggulangan bencana di Indonesia.

Matahari Department Store Tbk. (LPPF)

LPPF menyadari bahwa tanggungjawab sosial perusahaan harus mampu mereduksi dampak negatif operasional perusahaan baik terhadap lingkungan dan masyarakat. LPPF memandang CSR sebagai upaya disemua unit dalam perusahaan 
Tabel. 2 Program CSR ERAA Tahun 2017-2019

\begin{tabular}{|c|c|c|c|c|}
\hline No & Aspek & 2017 & 2018 & 2019 \\
\hline 1 & $\begin{array}{l}\text { Aspek } \\
\text { Sosial }\end{array}$ & $\begin{array}{l}\text { 1. Renovasi PAUD } \\
\text { 2. Bantuan } \\
\text { peralatan belajar } \\
\text { 3. Pelatihan dan } \\
\text { seminar guru } \\
\text { PAUD } \\
\text { 4. Donor darah } \\
\text { 5. Cahaya lentera } \\
\text { 6. Perayaan hari } \\
\text { besar } \\
\text { 7. Bakti sosial } \\
\text { 8. Program bantuan } \\
\text { bencana }\end{array}$ & $\begin{array}{l}\text { 1. Lentera } \\
\text { Cerdas } \\
\text { (Hi Smart } \\
\text { Teacher, } \\
\text { Smart } \\
\text { Parent, } \\
\text { dan } \\
\text { Erajaya } \\
\text { Mengajar) } \\
\text { 2. Donor } \\
\text { darah } \\
\text { 3. Cahaya } \\
\text { lentera }\end{array}$ & $\begin{array}{l}\text { 1. Tanggap bencana } \\
\text { 2. Donor darah } \\
\text { 3. Bantuan sosial } \\
\text { 4. Launching aplikasi } \\
\text { EmiL untuk } \\
\text { pembelajaran }\end{array}$ \\
\hline 2 & $\begin{array}{c}\text { Aspek } \\
\text { Ekonomi }\end{array}$ & $\begin{array}{c}\text { Lentera Cerdas } \\
\text { (Pelatihan service } \\
\text { handphone) }\end{array}$ & - & $\begin{array}{c}\text { Kelompok Tani Binaan } \\
\text { Good Partner }\end{array}$ \\
\hline 3 & $\begin{array}{c}\text { Aspek } \\
\text { Lingkungan }\end{array}$ & $\begin{array}{l}\text { Penghijauan } \\
\text { lingkungan }\end{array}$ & $\begin{array}{l}\text { Penghijauan } \\
\text { lingkungan }\end{array}$ & $\begin{array}{l}\text { 1. Persemaian } \\
\text { tanaman langka } \\
\text { 2. Greenpowerment }\end{array}$ \\
\hline
\end{tabular}

Tabel. 3 Program CSR LPPF Tahun 2017-2019

\begin{tabular}{|c|c|c|c|c|}
\hline No & Aspek & 2017 & 2018 & 2019 \\
\hline 1 & $\begin{array}{l}\text { Aspek } \\
\text { Sosial }\end{array}$ & $\begin{array}{l}\text { 1. Dalam dunia } \\
\text { pendidikan: } \\
\text { Beasiswa, } \\
\text { donasi, } \\
\text { pembangunan } \\
\text { sarana } \\
\text { pendidikan } \\
\text { 2. Sumbangan } \\
\text { amal } \\
\end{array}$ & $\begin{array}{l}\text { 1. Dalam dunia } \\
\text { pendidikan: } \\
\text { Beasiswa, } \\
\text { donasi, } \\
\text { pembangunan } \\
\text { sarana } \\
\text { pendidikan } \\
\text { 2. Sumbangan } \\
\text { amal } \\
\end{array}$ & $\begin{array}{l}\text { 1. Dalam dunia } \\
\text { pendidikan: } \\
\text { Beasiswa, } \\
\text { donasi, } \\
\text { pembangunan } \\
\text { sarana } \\
\text { pendidikan } \\
\text { 2. Sumbangan } \\
\text { amal } \\
\end{array}$ \\
\hline 2 & $\begin{array}{c}\text { Aspek } \\
\text { Ekonomi }\end{array}$ & $\begin{array}{l}\text { Pemanfaatan } \\
\text { tenaga kerja lokal }\end{array}$ & $\begin{array}{l}\text { Pemanfaatan } \\
\text { tenaga kerja lokal }\end{array}$ & $\begin{array}{l}\text { Pemanfaatan } \\
\text { tenaga kerja lokal }\end{array}$ \\
\hline 3 & $\begin{array}{c}\text { Aspek } \\
\text { Lingkungan }\end{array}$ & $\begin{array}{l}\text { 1. Penggunaan } \\
\text { energi } \\
\text { ramah } \\
\text { lingkungan } \\
\text { 2. Pengolahan } \\
\text { limbah }\end{array}$ & $\begin{array}{l}\text { 1. Penggunaan } \\
\text { energi } \\
\text { ramah } \\
\text { lingkungan } \\
\text { 2. Pengolahan } \\
\text { limbah }\end{array}$ & $\begin{array}{l}\text { 1. Penggunaan } \\
\text { energi } \\
\text { ramah } \\
\text { lingkungan } \\
\text { 2. Pengolahan } \\
\text { limbah }\end{array}$ \\
\hline
\end{tabular}


sehingga LPPF mendorong keterlibatan masyarakat dan pelanggan menciptakan masyarakat yang lebih adil dan berkelanjutan. Berikut beberapa program CSR yang dijalankan oleh LPPF sejak tahun 2017-2019.

Berdasarkan analisis terhadap laporan tahunan, diketahui bahwa perusahaan ritel telah melaksanakan CSR secara berkelanjutan. Hal ini dibuktikan dengan konsistensi pelaporan kegiatan CSR dalam laporan tahunan perusahaan. Dilihat dari laporan CSR, perusahaan ritel yang dijadikan objek penelitian melaporkan kegiatan CSR yang tidak terpisah dengan laporan tahunan (annual report).

Dalam melaksanakan kegiatan CSR, perusahaan memiliki payung masing-masing. Sebut saja ACES yang menggunakan Kawan Lama Foundation yang kegiatannya berkaitan dengan pendidikan, bantuan sosial, hingga lingkungan. ERAA menggunakan Lentera - Era Jaya peduli yang fokus pada aspek pendidikan, kesehatan, dan kesejahteraan sosial.

Perusahaan ritel yang menjadi objek penelitian telah memenuhi setidaknya 3 aspek, yakni sosial (termasuk pendidikan), ekonomi dan lingkungan. Aspek sosial diantaranya memberikan perhatian penuh kepada masyarakat yang kebutuhan, menjalin hubungan yang baik, memberikan fasilitas mendukung, penghijauan lingkungan sekitar, dan beasiswa (Yapiter, 2017). Praktik CSR pada aspek sosial didominasi dengan pemberian bantuan untuk dunia pendidikan berupa beasiswa maupun renovasi gedung sekolah. Selain itu, bantuan sosial pada bencana alam dan kegiatan donor darah juga menjadi pilihan aktivitas CSR perusahaan.

Aspek ekonomi berkaitan dengan peningkatan kesejahteraan masyarakat baik yang berada dalam wilayah operasional maupun diluar. ACES merupakan satu perusahaan yang fokus pada aspek sosial sehingga masih kurang untuk aspek ekonomi. ERAA memiliki kegiatan CSR yang berkaitan dengan aspek ekonomi. Pada tahun 2017, ERAA melakukan kerjasama dengan lembaga pendidikan terapan teknologi Indonesia melaksanakan program pelatihan service handphone kepada 19 peserta yang merupakan masyarkat putus sekolah. Pada tahun 2019, ERAA lebih progresif lagi dalam aspek ekonomi dengan melibatkan kelompok tani binaan. Sedangkan LPPF masih mengandalkan pemanfaatan tenaga kerja setempat sebagai upaya peningkatan kesejahteraan masyarakat. 
Aspek lingkungan berkaitan dengan perbaikan kualitas lingkungan dan meminimalisir dampak negatif operasi perusahaan bagi lingkungan. Program tanam pohon dan hemat energi masih menjadi program unggulan perusahaan ritel dalam aspek lingkungan. Walau tidak seperti perusahaan tambang yang langsung berkaitan dengan lingkungan, perusahaan ritel juga mempertimbangkan limbah operasionalnya. LPPF merupakan contoh perusahaan ritel yang pada tahun 2019 telah menggunakan tas belanja yang berbasis singkong.

Berdasarkan data-data yang sudah dijelaskan, terlihat bahwa CSR dari perusahaan ritel sudah berperan penting dalam peningkatan dalam bidang sosial, ekonomi, dan lingkungan. Porsi aspek sosial yang menjadi aspek dengan kegiatan tertinggi menandakan bahwa CSR yang dilakukan perusahaan ritel masih terkait kegiatan donasi atau sumbangan. Hal ini perlu didorong agar aspek ekonomi menjadi lebih mendapat perhatian.

Konsep CSR dengan menitikberatkan pada Community Development (Comdev) diperlukan agar masyarakat lebih berdikari dalam hal ekonomi. Program Lentera Cerdas oleh ERAA menjadi contohnya. Bahkan ditahun 2019, ERAA meluncurkan program kelompok tani binaan. Program ini bersifat jangka panjang dengan memberikan pemahaman kepada kelompok tani terkait product knowledge, packaging, finansial, dan penjualan dari jenis usaha yang telah dilakukan.

Adanya peran serta karyawan dan masyarakat umum pada program CSR perusahaan retail merupakan suatu modal bagus dalam jaminan program CSR akan berkelanjutan. Keterlibatan karyawan dan masyarakat haru dilakukan mulai dari tahap perencanaan program, pelaksanaan hingga evaluasi dan tindaklanjut

\section{KESIMPULAN, IMPLIKASI DAN KETERBATASAN PENELITIAN}

Corporate Social Responsibility (CSR) merupakan program tanggungjawab sosial perusahaan yang berdasar pada konsep triple bottom line (3P), yakni Profit, People, dan Planet. Perusahaan ritel yang merupakan pelaku bisnis perseroan diwajibkan untuk melaksanakan CSR sesuai ketentuan yang berlaku.

CSR dari perusahaan ritel secara berkelanjutan telah berdampak pada aspek sosial, ekonomi maupun lingkungan. Keterlibatan karyawan dan masyarakat dalam perencanaan, 
pelaksanaan, hingga evaluasi program CSR perusahaan merupakan bukti keberlanjutan dari sebuah program.

Bagi perusahaan retail, program CSR yang telah dilaksanakan harus lebih menitikberatkan pada Community Development (Comdev) yang berbasis masyarakat (community based), berbasis sumber daya setempat (local resource based) dan berkelanjutan (sustainable). Selain itu, proses evaluasi program secara berkelanjutan perlu dilakukan agar terjadi perbaikan yang berdampak pada Comdev yang lebih baik

\section{REFERENSI}

Bell, F., \& Lehman, G. (1999). Recent Trends in Environment Accounting: How Green are your Account. Accounting Forum, 1-10.

CEIC. (2020). Indonesia Pertumbuhan Penjualan Ritel. Https://Www.Ceicdata.Com/Id/I ndicator/Indonesia/Retail-SalesGrowth.

Mattera, M., \& Alberto, M. (2016). Strategic Implications of Corporate Responsibility in Hotel Industry: A Comparative Research Between NH Hotel adn Melia Hotels International. Universidad Europea de Madrid.

Satriyarti, \& Rahayu, D. (2018). Upaya Pengentasan Kemiskinan di Madura sebagai Model Pengembngan Tanggung Jawab Sosial. Masyarakat, Kebudayaan Dan Politik.
Sidarta, I. (2018). Dampak Perkembangan Pariwisata Terhadap Kondisi Lingkungan, Sosial, dan Ekonomi Masyarakat. Alfabeta.

Sidarta, I. W. (2016). Dampak Perkembangan Pariwisata Terhadap Kondisi Lingkungan Sosial, dan Ekonomi Masyarakat Semarang. JANKUR.

Sofyanty, Y. R., Hamid, D., \& Dewantara, R. Y. (2017). Analisis Penerapan Csr Dan Dampaknya Terhadap Kehidupan Sosial Ekonomi Masyarakat (Studi Kasus Pada Hotel Ibis Surabaya City Center). Jurnal Administrasi Bisnis (JAB).

Sopiah, \& Syihabudhin. (2008). Manajemen Bisnis Ritel. Andi Yogyakarta.

Wahudi, I., \& Azheri, B. (2008). Corporate Social Responsibility: Prinsip, Pengaturan \& Implementasi. In Trans.

Wibisono, Y. (2007). Membeda Konsep \& Aplikasi CSR. Fascho Publishing.

Yapiter, M. P. (2013). Penerapan Prinsip-Prinsip Good Corporate Governance Pada Program CSR Hotel $X$ Di Kupang. Universitas Surabaya.

Yapiter, M. P. (2017). Penerapan Prinsip-Prinsip Good Corporate govermence Pada Program CSR Hotel X Di Kupang. JAB. 